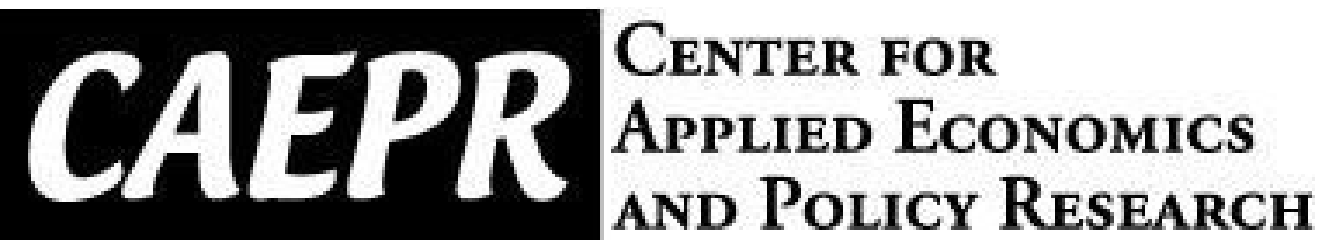

GAEPR Working Paper
\#2015-010

\title{
Fiscal Rules and the Sovereign Default Premium
}

\author{
Juan Carlos Hatchondo \\ Indiana University \\ Leonardo Martinez \\ IMF \\ Francisco Roch \\ IMF
}

March 20, 2015

This paper can be downloaded without charge from the Social Science Research Network electronic library at http://papers.ssm.com/sol3/papers.cfm?abstract id=2625128 The Center for Applied Economics and Policy Research resides in the Department of Economics at Indiana University Bloomington. CAEPR can be found on the Internet at:

http://www.indiana.edu/ caepr. CAEPR can be reached via email at caepr@indiana.edu or via phone at 812-855-4050.

(C2015 by Juan Carlos Hatchondo, Leonardo Martinez and Francisco Roch. All rights reserved. Short sections of text, not to exceed two paragraphs, may be quoted without explicit permission provided that full credit, including (C) notice, is given to the source. 


\title{
Fiscal rules and the sovereign default premium*
}

\author{
Juan Carlos Hatchondo Leonardo Martinez Francisco Roch \\ Indiana University IMF IMF
}

March 20, 2015

\begin{abstract}
We use a sovereign default model to study the effects of introducing limits to the decisionmaking capabilities of governments - fiscal rules. We show that optimal limits to the debt level vary greatly across parameterizations of the model that deliver different levels of debt tolerance. In contrast, optimal limits to the sovereign premium paid by the government are very similar across parameterizations. Since levels of debt tolerance are difficult to identify and vary both across countries and over time, and political constraints often force common fiscal rule targets across countries, these findings indicate that sovereign-premium limits may be preferable to debt limits.

JEL classification: F34, F41.

Keywords: Fiscal Rules, Debt Limit, Spread Limit, Default, Sovereign Default Premium, Countercyclical Policy, Endogenous Borrowing Constraints, Long-term Debt, Debt Dilution, Debt Tolerance.
\end{abstract}

\footnotetext{
*For their comments and suggestions, we thank Satyajit Chatterjee, Gaston Gelos, Lars Hansen, Eric Leeper, Xavier Mateos-Planas, Enrique Mendoza, Benjamin Moll, Demian Pouzo, Jorge Roldos, Harald Uhlig, and seminar participants in the University of Chicago, Banco de Mexico, Universidad del CEMA, Getulio Vargas, Universidad Catolica de Chile, the 2011 European Economic Association and Econometric Society Meeting, the 2012 Sovereign Debt Workshop at the Federal Reserve Bank of Richmond, the 2014 North American Winter Meeting of the Econometric Society, the 2014 Barcelona GSE Summer Forum, the University of Toronto, the IMF Institute, and the IMF Strategy, Policy, and Review Department. All remaining mistakes are our own. The views expressed herein are those of the authors and should not be attributed to the IMF, its Executive Board, or its management. E-mails: juanc.hatchondo@gmail.com; leo14627@gmail.com; franroch@gmail.com.
} 


\section{Introduction}

Fiscal rules are restrictions imposed (often in laws or in the constitution) upon future governments' ability to conduct fiscal policy. While there is consensus among policymakers on the desirability of fiscal rules targeting lower sovereign debt levels, significant uncertainty remains about the optimal value of fiscal rules' targets. ${ }^{1}$ More generally, while optimal sovereign debt levels are often at the center of policy debates, these debates are rarely guided by economic theory. For example, the IMF chief economist asked: "What levels of public debt should countries aim for? Are old rules of thumb, such as trying to keep the debt-to-GDP ratio below 60 percent in advanced countries, still reliable?" (Blanchard, 2011). ${ }^{2}$

This paper studies the optimal value of fiscal rules' targets and quantifies the effects of introducing fiscal rules using a baseline sovereign default framework à la Eaton and Gersovitz (1981). ${ }^{3}$ We develop an infinite-horizon model in which aggregate output is determined by an aggregate productivity shock and labor-leisure decisions made by domestic households. The benevolent government produces a public good consumed by domestic households and finances the provision of this good by levying labor taxes and issuing long-term defaultable debt. If the government defaults on its debt, it is excluded from credit markets for a stochastic number of periods, during which aggregate productivity is reduced. We then study the optimality and robustness of two different fiscal rules that limit either the debt level or the maximum sovereign premium the government can pay when it increases its debt level.

\footnotetext{
${ }^{1}$ For instance, in an IMF Staff Position Note, Blanchard et al. (2010) argue that "A key lesson from the crisis is the desirability of fiscal space to run larger fiscal deficits when needed." They also note that "Medium-term fiscal frameworks, credible commitments to reducing debt-to-GDP ratios, and fiscal rules (with escape clauses for recessions) can all help in this regard." Discussions about the overhaul of the fiscal rules of the Eurozone provide other examples of this view.

${ }^{2}$ Similarly, the IMF flagship fiscal publication has recently stated that "the optimal-debt concept has remained at a fairly abstract level, whereas the safe-debt concept has focused largely on empirical applications" (IMF, 2013a).

${ }^{3}$ This framework is commonly used for quantitative studies of sovereign debt and has been shown to generate plausible implications for sovereign debt and the sovereign default premium. See, for instance, Aguiar and Gopinath (2006), Arellano (2008), Bianchi et al. (2012), Cuadra and Sapriza (2008), D'Erasmo (2011), Durdu et al. (2013) Boz (2011), Lizarazo (2005, 2006), Pouzo and Presno (2013, 2014), Roch and Uhlig (2014), Sandleris et al. (2011) and Yue (2010). This model shares blueprints with the ones used in studies of household defaultsee, for example, Athreya et al. (2007), Chatterjee et al. (2007), Li and Sarte (2006), Livshits et al. (2008), and Sanchez (2010). For models of non-strategic default, see Bi (2011) and Bi and Leeper (2012).
} 
We first consider a simpler version of the model to show analytically how, in the presence of sovereign risk, the introduction of a fiscal rule may generate welfare gains when governments issue long-term debt. Without a fiscal rule, the government cannot lower the level of sovereign risk (and thus increase the price of current debt issuances) by committing to lower levels of future debt issuances (each period, lowering the price of debt issued in previous periods is not a cost of issuing debt; the debt dilution problem). Fiscal rules allow the government to do so.

We then use the quantitative model to study the effects of fiscal rules for a range of parameterizations that produce plausible levels of sovereign debt tolerance (i.e., of the relationship between the level of sovereign debt and the sovereign default premium). This is relevant because there is evidence of cross-country heterogeneity in debt tolerance (Reinhart et al., 2003) and political constraints often force common fiscal rule targets across countries (perhaps the best-known example is the common sovereign debt limit imposed by the Maastricht Treaty). ${ }^{4}$ Furthermore, identifying the level of debt tolerance may be difficult, and this level may change over time (Reinhart et al., 2015). Consequently, it would be desirable that gains from imposing fiscal rules are robust across levels of debt tolerance. We impose discipline on our quantitative exercises by calibrating the model to match data from a European economy facing default risk (Spain), and study the effects of fiscal rules for a range of variations of this baseline calibration. ${ }^{5}$

We find that the optimal debt limits vary greatly across levels of debt tolerance: the limit that is optimal for our baseline calibration may fail to produce welfare gains for other parameterizations. In contrast, fiscal rules limiting the sovereign premium the government can pay while increasing its debt level are more robust: the optimal premium limit for the baseline calibration consistently produces welfare gains for other parameterizations. Moreover, optimal sovereign-premium limits are very similar across parameterizations.

It is intuitive that sovereign-premium limits have greater robustness than debt limits. We show that gains from imposing fiscal rules arise because rules achieve a reduction in sovereign

\footnotetext{
${ }^{4}$ Common sovereign debt thresholds are also used across countries by the IMF, as one of the criteria for deciding on the level of scrutiny to be applied in surveillance (IMF, 2013b; IMF, 2013c).

${ }^{5}$ In a previous version of this paper, we found similar results for variations of a baseline calibration targeting Argentine data, and thus presenting levels of debt tolerance lower than those of European economies and more typical of emerging economies (i.e., lower debt levels with higher sovereign premium levels).
} 
risk. Debt limits are too blunt of an instrument for that goal. A debt limit that is too loose may fail to achieve the desired risk reduction. A debt limit that is too tight may unnecessarily prevent a government from borrowing, reducing the scope for welfare gains from fiscal rules, and even producing welfare losses. In contrast, limits to the sovereign premium attack directly the problem of excessive sovereign risk.

The unstable relationship between monetary aggregates and interest rates has led many central banks to move from setting objectives for the level of monetary aggregates to setting objectives directly for interest rates. This paper suggests that perhaps the unstable relationship between sovereign debt levels and the sovereign premium is reason to shift the focus of discussions of fiscal policy from setting objectives for debt levels to setting objectives for the sovereign premium. Maybe we should ask what levels of sovereign premium countries should target, instead of asking what levels of public debt they should aim for. ${ }^{6}$

For the findings described above, we assume that governments can commit to a fiscal rule. Empirical studies find that well-designed fiscal rules improve fiscal outcomes, indicating that governments can commit to these rules. For instance, Heinemann et al. (2014) and Iara and Wolff (2011) find that fiscal rules reduce the sovereign premium of European bonds. Feld et al. (2013), Lowry and Alt (2001), and Poterba and Rueben (1999) present similar evidence for subnational governments in the U.S. and Switzerland. Other empirical studies find that fiscal rules are associated with stronger fiscal performance (Corbacho and Schwartz, 2007; Debrun and Kumar, 2007; Debrun et al., 2008; Deroose et al., 2006; EC, 2006; Kopits, 2004). ${ }^{7}$

In addition, policymakers are making efforts to enhance the compliance with fiscal rules.

\footnotetext{
${ }^{6}$ While policy debates are dominated by sovereign debt levels, the role of sovereign premiums in these debates is growing. For instance, Claessens et al. (2012) argue that "the challenge is to complement fiscal rules affecting quantities most productively with market-based mechanisms using price signals." In addition, recent revisions of the IMF fiscal sustainability framework incorporate sovereign spreads as an additional criteria to guide the level of scrutiny in surveillance (IMF, 2013b). We complement the sustainability analysis (Adler and Sosa, 2013; Ghosh et al., 2011; Tanner and Samaké, 2006) commonly used in policy circles (see, e.g., IMF, 2013c, and IMF Article IV country reports) by modeling endogenous sovereign spreads (that, for example, capture the effects of the expectation of future fiscal adjustments), endogenous borrowing policies (which react to fiscal rules), and a welfare criterion to discuss optimal policy.

${ }^{7}$ Difficulties in identifying the effects of fiscal rules are well documented (Poterba, 1996; Heinemann et al., 2014). When comparing predictions in this paper with past experiences with fiscal rules, one should keep in mind that we are assuming certainty about the government's ability to commit to enforcing a rule, but such certainty has often been lacking in experiences to date.
} 
According to the IMF Fiscal Rules and Fiscal Councils Datasets, 89 countries have numerical fiscal rules (setting objectives for revenues, expenditures, budget balances, and debt), and 34 have fiscal bodies to independently assess fiscal policies, including setting budget assumptions and monitoring the implementation of fiscal rules (Budina et al., 2012; Schaechter et al., 2012). In addition, fiscal rules are being complemented with automatic sanctioning and enforcement procedures (see, for instance, Germany's and Switzerland's debt brakes, and other automatic correction mechanisms such as "sequestration" processes). Furthermore, countries continue to strengthen the legal basis of fiscal rules. For example, Germany (in 2009) and Spain (in 2011) amended their constitutions to introduce fiscal rules. The super-majorities, referendums, or waiting periods typically required to amend a constitution limit the discretionary power of policymakers in office. Fiscal rules based on market discipline (as advocated in this paper) could be less susceptible to accounting manipulations. ${ }^{8}$

We also present measures of a government's gain from abandoning its fiscal rule in our framework. We find that for debt-limit and sovereign-premium-limit rules this gain is relatively small: up to 1.1 percent of annual output if the government could reinstate the rule one quarter after abandoning it, and negative (up to -1.4 percent) if the government cannot restore the rule. Thus, the enforcement needed to prevent deviations from rules limiting the debt level or the sovereign premium would be modest. In contrast, we study a fiscal rule that does not allow the government to default and show that the gain from abandoning this rule may be very large (up to 12.4 percent of annual output).

\subsection{Related Literature}

In spite of the great interest among policymakers, theoretical studies of fiscal rules are relatively scarce. Some theoretical studies focus on the desirability of a balanced-budget rule for the U.S. federal government (see Azzimonti et al., 2010 and the references therein). Garcia et al. (2011) compare a balanced budget rule with a structural surplus rule. Beetsma and Uhlig (1999) show how by imposing lower debt levels, the Stability and Growth Pact may help control

\footnotetext{
${ }^{8}$ Hatchondo et al. (2014a) argue that sovereign debt covenants could help enforce fiscal rules.
} 
inflation in the European Monetary Union. Beetsma and Debrun (2007) discuss how additional flexibility in the Stability and Growth Pact may improve welfare. Pappa and Vassilatos (2007) and Poplawski Ribeiro et al. (2008) argue that debt limits may be preferable over constraints on the government's deficit. Medina and Soto (2007) use a model of the Chilean economy to show that a structurally balanced fiscal rule mitigates the macroeconomic effects of copper-price shocks.

The studies listed in the previous paragraph do not discuss the robustness of debt limits, nor do they discuss sovereign-premium limits, which are the main focus of our analysis. Furthermore, these studies abstract from the effects of the expectation of future indebtedness on the sovereign premium, which we show is key for the gains of imposing fiscal rules in our environment. In these studies, rules may be beneficial because of a conflict of interest between the government and private agents (for instance, because the government is myopic or because of political polarization), or because of a conflict of interest among the governments of different countries (for instance, in a monetary union). In contrast, we study a model with benevolent governments but in which there is a conflict between current and future governments. We show that benefits from imposing a rule arise even when governments are not shortsighted. We also show how assuming shortsighted governments would imply greater gains from implementing fiscal rules and stricter fiscal rule limits.

As we do, Calvo (1988) discuses gains from introducing interest-rate limits for sovereign debt. However, there are important differences between the two analyses. In Calvo's (1988) model, an interest-rate limit is used to eliminate bad equilibria in a multiple-equilibria framework. Calvo (1988), and more recently, Lorenzoni and Werning (2014) assume that the government first chooses the proceeds from debt issuances it needs, and the lenders later choose what interest rate they ask for to finance the government's needs. Since higher debt levels imply more default risk and thus higher interest rates, the government's needs can be financed in either a good, low-debt, low-rate equilibrium or a bad, high-debt, high-rate equilibrium. An interest-rate limit eliminates the possibility of a bad equilibrium. In contrast, we assume that the government chooses the level of debt it wants to issue (instead of the proceeds from debt issuances), eliminating the possibility of a bad equilibrium à la Calvo-Lorenzoni-Werning. We show that fiscal rules are beneficial even 
after abstracting for the possibility of multiple equilibria. In our framework, gains from the fiscal rule appear because of debt dilution, a time-inconsistency problem that arises when governments issue long-term debt.

An extensive literature discusses the importance of sovereign debt dilution (see Hatchondo et al., 2014a and the references therein). Within this literature, Chatterjee and Eyigungor (2013) and Hatchondo et al. (2014a) present the studies that are closest to this paper. As we do, they study the quantitative effects of remedies to the dilution problem. While we focus on fiscal rules, the tools countries are using to deal with sovereign debt problems (Budina et al., 2012; IMF, 2009; Schaechter et al., 2012), Chatterjee and Eyigungor (2013) and Hatchondo et al. (2014a) discuss the effects of modifying sovereign debt contracts. Chatterjee and Eyigungor (2013) study the effects of introducing a seniority structure, and Hatchondo et al. (2014a) study the effects of introducing debt covenants that penalize future borrowing.

The paper also contributes to the discussion of the optimal cyclicality of fiscal policy. Cuadra et al. (2010) show that in a sovereign default model with one-period debt and without a fiscal rule, it is optimal for the government to borrow less when income is low. Thus, the optimal fiscal policy is procyclical. ${ }^{9}$ We show that the same is true in our benchmark no-rule model with long-term debt. Furthermore, we show that in the presence of sovereign risk, if the government can limit future policy choices with a fiscal rule, it may still not want to use the rule to promote countercyclical policies.

The rest of the article proceeds as follows. Section 2 presents a three-period model that allows us to illustrate how a benevolent government may benefit from a fiscal rule that constrains its behavior. Section 3 introduces the quantitative model. Section 4 discusses the calibration. Section 5 presents the results. Section 6 concludes.

\footnotetext{
${ }^{9}$ This is consistent with the observed fiscal policy in emerging economies, as documented by Gavin and Perotti (1997), Ilzetzki et al. (2012), Kaminsky et al. (2004), Talvi and Végh (2009), and Végh and Vuletin (2011).
} 


\section{A three-period model}

This section presents a simple environment that illustrates how the introduction of fiscal rules may produce welfare gains. The next section builds on this simple environment and expands it in several dimensions.

\section{$2.1 \quad$ Environment}

The economy lasts for three periods, $t=1,2,3$. The government receives a sequence of endowments, given by $y_{1}=0, y_{2}=0$, and $y_{3}>0$. The only uncertainty in the model is about the value of $y_{3}$. The government is benevolent and makes its decisions on a sequential basis. The government acting in period $j \in\{1,2,3\}$ maximizes $\mathbb{E}\left[\sum_{t=j}^{3} u\left(c_{t}\right)\right]$, where $\mathbb{E}$ denotes the expectation operator, $c_{t}$ represents period- $t$ consumption in the economy, and the utility function $u$ is increasing and concave.

The government can borrow to finance consumption in periods 1 and 2. A bond issued in period 1 promises to pay one unit of the good in period 2 and $(1-\delta)$ units in period 3 . Thus, if $\delta=1$, the government issues one-period bonds in period 1. If $\delta<1$, the government issues long-term bonds in period 1 . A bond issued in period 2 promises to pay one unit of the good in period 3 .

The government may choose to default in period $3 .{ }^{10}$ If the government defaults, it does not pay its debt but looses a fraction $\phi$ of the period-3 endowment $y_{3}$. Bonds are priced by competitive risk-neutral investors who discount future payments at a rate of 1.

Let $b_{t}$ denote the number of bonds issued by the government and $q_{t}$ the price at which the government sells bonds in period $t$. The budget constraints are:

$$
\begin{gathered}
c_{1}=b_{1} q_{1}\left(b_{1}, b_{2}\right), \\
c_{2}=b_{2} q_{2}\left(b_{1}, b_{2}\right)-b_{1}, \\
c_{3}=y_{3}(1-d \phi)-(1-d)\left[b_{1}(1-\delta)+b_{2}\right],
\end{gathered}
$$

\footnotetext{
${ }^{10}$ In period 2 , since no new information is revealed, there cannot be a meaningful default decision.
} 
where $d$ denotes the government's default decision and is equal to 1 if the government defaults and to 0 otherwise.

\section{$2.2 \quad$ Results}

In this setup, it is optimal to borrow because borrowing enables the government to smooth out consumption over time. However, borrowing decisions are restricted by the limited commitment problem faced by the government.

The equilibrium default decision is given by

$$
\hat{d}\left(b_{1}, b_{2}, y_{3}\right)=\left\{\begin{array}{l}
1 \quad \text { if } y_{3}<\frac{b_{1}(1-\delta)+b_{2}}{\phi}, \\
0 \quad \text { otherwise. }
\end{array}\right.
$$

Given the above defaulting rule, the price of a bond issued in period 1 is given by

$$
q_{1}\left(b_{1}, b_{2}\right)=1+(1-\delta) P\left[y_{3}>\frac{b_{1}(1-\delta)+b_{2}}{\phi}\right]
$$

where $P$ denotes the probability function. The price of a bond issued in period 2 is given by

$$
q_{2}\left(b_{1}, b_{2}\right)=P\left[y_{3}>\frac{b_{1}(1-\delta)+b_{2}}{\phi}\right] .
$$

Since the government does not borrow in period 3 , there is no role for rules that limit the government behavior in that period. It is easy to verify that there is also no role for rules in period 1. Proposition 1 shows that when the government can only issue one-period debt, there is no role for fiscal rules in period 2 .

Proposition 1 Suppose $\delta=1$; i.e., bonds issued in period 1 pay off in period 2 alone. Then, the government's period 1 expected utility cannot be improved with a fiscal rule that limits debt choices in period 2.

Proof: The government's period 1 expected utility is maximized by $b_{1}^{*}$ and $b_{2}^{*}$ such that

$$
u^{\prime}\left(c_{1}^{*}\right)=u^{\prime}\left(c_{2}^{*}\right)=\frac{\mathbb{E}\left[u^{\prime}\left(c_{3}^{*}\right)\left[1-\hat{d}\left(b_{1}^{*}, b_{2}^{*}, y_{3}\right)\right]\right]}{q_{2}\left(b_{1}^{*}, b_{2}^{*}\right)+b_{2}^{*} \frac{\partial q_{2}\left(b_{1}^{*}, b_{2}^{*}\right)}{\partial b_{2}}},
$$


where

$$
\begin{gathered}
c_{1}^{*}=b_{1}^{*} q_{1}\left(b_{1}^{*}, b_{2}^{*}\right), \\
c_{2}^{*}=b_{2}^{*} q_{2}\left(b_{1}^{*}, b_{2}^{*}\right)-b_{1}^{*}, \\
c_{3}^{*}=y_{3}\left[1-\hat{d}\left(b_{1}^{*}, b_{2}^{*}, y_{3}\right) \phi\right]-\left[1-\hat{d}\left(b_{1}^{*}, b_{2}^{*}, y_{3}\right)\right] b_{2}^{*} .
\end{gathered}
$$

A government's period 2 optimal choice satisfies

$$
u^{\prime}\left(c_{2}\right)=\frac{\mathbb{E}\left[u^{\prime}\left(c_{3}\right)\left[1-\hat{d}\left(b_{1}, b_{2}, y_{3}\right)\right]\right]}{q_{2}\left(b_{1}, b_{2}\right)+b_{2} \frac{\partial q_{2}\left(b_{1}, b_{2}\right)}{\partial b_{2}}} .
$$

Thus, if the government chooses $b_{1}^{*}$ in period 1 , it is expected that the government acting in period 2 will choose $b_{2}^{*}$. This means that the government's period 1 expected utility cannot be improved with a period 2 fiscal rule.

Proposition 2 shows that a role for fiscal rules arises when the government issues long-term debt (in period 1).

Proposition 2 Suppose $\delta<1$; i.e., the government issues long-term debt in period 1. Then, a period 2 fiscal rule is needed to maximize the government's period 1 expected utility.

Proof: The government's period 1 expected utility is maximized by $b_{1}^{*}$ and $b_{2}^{*}$, such that

$$
\begin{gathered}
u^{\prime}\left(c_{1}^{*}\right)\left[q_{1}\left(b_{1}^{*}, b_{2}^{*}\right)+b_{1}^{*} \frac{\partial q_{1}\left(b_{1}^{*}, b_{2}^{*}\right)}{\partial b_{1}}\right]=u^{\prime}\left(c_{2}^{*}\right)\left[1-b_{2}^{*} \frac{\partial q_{2}\left(b_{1}^{*}, b_{2}^{*}\right)}{\partial b_{1}}\right]+(1-\delta) \mathbb{E}\left[u^{\prime}\left(c_{3}^{*}\right)\left[1-\hat{d}\left(b_{1}^{*}, b_{2}^{*}, y_{3}\right)\right]\right], \\
u^{\prime}\left(c_{2}^{*}\right)\left[q_{2}\left(b_{1}^{*}, b_{2}^{*}\right)+b_{2}^{*} \frac{\partial q_{2}\left(b_{1}^{*}, b_{2}^{*}\right)}{\partial b_{2}}\right]=\mathbb{E}\left[u^{\prime}\left(c_{3}^{*}\right)\left[1-\hat{d}\left(b_{1}^{*}, b_{2}^{*}, y_{3}\right)\right]\right]-u^{\prime}\left(c_{1}^{*}\right) b_{1}^{*} \frac{\partial q_{1}\left(b_{1}^{*}, b_{2}^{*}\right)}{\partial b_{2}}
\end{gathered}
$$

The government's period-2 optimal choice satisfies

$$
u^{\prime}\left(c_{2}\right)\left[q_{2}\left(b_{1}, b_{2}\right)+b_{2} \frac{\partial q_{2}\left(b_{1}, b_{2}\right)}{\partial b_{2}}\right]=\mathbb{E}\left[u^{\prime}\left(c_{3}\right)\left[1-\hat{d}\left(b_{1}, b_{2}, y_{3}\right)\right]\right]
$$


Since equation (4) is different from (3), the allocation that maximizes the government's period 1 expected utility cannot be attained without a fiscal rule (if the period 1 government chooses $b_{1}^{*}$, the period 2 government will not choose $b_{2}^{*}$ ).

In contrast, the allocation that maximizes a government's period 1 expected utility can trivially be attained with a fiscal rule that forces the period 2 government to choose $b_{2}^{*}$ (with the period 1 government choosing $\left.b_{1}^{*}\right) .{ }^{11}$

The role for a fiscal rule arises because the rule eliminates the debt dilution problem. With long-term debt, period 2 debt issuances dilute the price of period 1 debt $\left(q_{1}\left(b_{1}, b_{2}\right)\right.$ is decreasing with respect to $b_{2}$ in equation 2). The allocation that maximizes the government's period 1 expected utility takes into account that the price of the debt issued in period 1 is negatively affected by debt issuances in period 2 (last term of the right-hand side of equation 3). But this is not a cost for the government acting in period 2 (equation 4). Consequently, in the absence of a fiscal rule, the period 2 government overborrows, exposing the period 1 government to excessive default risk (the optimal default rule in equation 1 implies that the default probability is increasing with respect to $b_{2}$ ).

Summing up, this section illustrates that there is no role for fiscal rules with one-period debt (proposition 1), but a fiscal rule is necessary to implement the optimal allocation with long-term debt (the empirically relevant case given the debt duration observed in the data). We next study a richer model that allows us to draw lessons for the design of fiscal rules and to quantify the gains that result from the introduction of fiscal rules. In particular, we show that rules limiting the sovereign default premium are more robust than rules limiting debt levels.

\section{The quantitative model}

We first present the benchmark model without fiscal rules, and then discuss how we model fiscal rules.

\footnotetext{
${ }^{11}$ Note that the allocation that maximizes the government's period 1 expected utility could be attained with a debt limit $b_{2} \leq b_{2}^{*}$ or a limit to the price at which the government can sell debt $q_{2}\left(b_{1}^{*}, b_{2}^{*}\right)$, as both these limits will make the period 2 government choose $b_{2}^{*}$.
} 


\subsection{The no-rule benchmark}

The domestic economy lives for an infinite number of periods and is populated by continua of firms and households. Aggregate output $y=e^{z} l$ is determined by an aggregate productivity shock $z$ and labor hours $l$. The logarithm of domestic productivity follows an AR(1) process:

$$
z_{t}=(1-\rho) \mu_{z}+\rho z_{t-1}+\varepsilon_{t}
$$

with $\varepsilon_{t} \sim N\left(0, \sigma_{\epsilon}^{2}\right)$.

The government's objective is to maximize the present expected discounted value of future utility flows of the representative household in the economy, namely

$$
\mathbb{E}_{t} \sum_{j=t}^{\infty} \beta^{j-t} u\left(c_{j}, g_{j}, 1-l_{j}\right),
$$

where $\mathbb{E}$ denotes the expectation operator, $\beta$ the subjective discount factor, $u$ the household's utility function, $c$ private consumption, and $g$ the public good provided by the government.

In each period, the representative household makes labor-leisure decisions by solving

$$
\begin{aligned}
& \max _{l} u(c, g, 1-l) \\
& \text { subject to } \\
& c=e^{z}(1-\tau) l,
\end{aligned}
$$

where $\tau$ denotes the labor tax rate, and thus $e^{z}(1-\tau)$ denotes the after-tax wage. The government finances $g$ with the distortionary labor $\operatorname{tax} \tau$ and with issuances of defaultable debt.

As in Hatchondo and Martinez (2009), we assume that a bond issued in period $t$ promises an infinite stream of coupons, with coupon payments decreasing at a constant rate $\delta$. In particular, a bond issued in period $t$ promises to pay one unit of the good in period $t+1$ and $(1-\delta)^{s-1}$ units in period $t+s$, with $s \geq 2$. The value of $\delta$ is calibrated to match the observed duration of sovereign debt in the data. In order to avoid increasing the computation cost, we do not allow the government to choose the maturity of sovereign debt. Studies with endogenous maturity find 
that in spite of the debt dilution problem, the government will choose to issue long-term debt in order to mitigate rollover risk (Arellano and Ramanarayanan, 2010; Hatchondo and Martinez, 2013; Hatchondo et al., 2014a). Furthermore, mitigating the dilution problem would allow the government to increase the average duration of sovereign debt in order to lessen rollover risk (Hatchondo et al., 2014a). This would constitute an additional benefit from introducing fiscal rules that we do not study here.

As in previous studies of sovereign default, we assume that the cost of defaulting is not a function of the size of the default. Thus, as in Arellano and Ramanarayanan (2010), Chatterjee and Eyigungor (2012) and Hatchondo and Martinez (2009), when the government defaults, it does so on all current and future debt obligations. This is consistent with the actual behavior of defaulting governments. Sovereign debt contracts often contain an acceleration clause and a cross-default clause. The first clause allows creditors to call the debt they hold in case the government defaults on a payment. The cross-default clause states that a default on any government obligation also constitutes a default on the contracts containing that clause. These clauses imply that after a default event, future debt obligations become current.

There are two costs of defaulting in the model. First, a defaulting sovereign is excluded from capital markets. Secondly, if a country has defaulted on its debt, it faces a productivity loss of $\phi(z)$ in every period during which it is excluded from capital markets.

Following Hatchondo et al. (2014a), we capture in a simple fashion the positive recovery rate of debt in default observed in the data (see Cruces and Trebesch, 2013, and Benjamin and Wright, 2008). Starting from the first period after the government defaults, the government is presented with the opportunity to end the default with time-invariant probability $\xi$. In order to end the default, the government needs to exchange the bonds that are in default with bonds that promise to pay $\alpha<1$ times the payments promised by the exchanged bonds. The government may choose to not restructure the debt and continue in default, in which case its debt level will still be $\alpha$ times the debt level before the restructuring opportunity (thus, the government can obtain a lower recovery rate at the expense of a longer default period). During default, the government's payment obligations grow at the interest rate $r$.

In a model with long-term debt, a positive recovery rate may give the government incen- 
tives to issue large amounts of debt before defaulting, which would allow for a large increase in consumption (Hatchondo et al., 2014b). Following Hatchondo et al. (2014a), in order to avoid this problem, we assume that the government cannot issue bonds at a price lower than $\underline{q}$ (the secondary market price of government debt can still be lower than $\underline{q}$ ). We choose a value of $\underline{q}$, which eliminates consumption booms before defaults. The chosen value is never binding in the simulations.

Bonds are priced in a competitive market inhabited by a large number of foreign investors. Thus, bond prices are pinned down by the foreign investors' zero-expected-profit condition. Foreign investors are risk-neutral and discount future payoffs at the rate $r$.

The timing within each period is as follows. At the beginning of each period a government not in default chooses whether to default, and a government in default may choose to end the default if it is presented with the opportunity to do so. At the end of each period the government chooses the level of public expenditures $g$, the labor tax rate, and when it is not in default, the number of bonds it wants to issue (or buy back).

We focus on Markov Perfect Equilibrium. That is, we assume that in each period, the government's equilibrium strategies depend only on payoff-relevant state variables.

\subsection{Recursive formulation of the no-rule benchmark}

Let $b$ denote the number of outstanding coupon claims at the beginning of the current period. Let $V$ denote the value function of a government that is not currently in default. This function satisfies the following functional equation:

$$
V(b, z)=\max \left\{V^{R}(b, z), V^{D}(b, z)\right\}
$$

where $V^{R}$ and $V^{D}$ denote, respectively, the continuation value when the government repays its debt obligations, and when it declares a default.

If the government repays its current debt obligations, it has to decide how many bonds to issue in the current period, the tax rate $(\tau)$, and the level of government expenditures $(g)$. The 
value function under repayment satisfies the following functional equation:

$$
V^{R}(b, z)=\max _{b^{\prime} \geq 0, c \geq 0, g \geq 0, \tau \geq 0}\left\{u(c, g, 1-l)+\beta \mathbb{E}_{z^{\prime} \mid z} V\left(b^{\prime}, z^{\prime}\right)\right\},
$$

subject to

$$
\begin{aligned}
& g=\tau e^{z} l-b+q\left(b^{\prime}, z\right)\left[b^{\prime}-(1-\delta) b\right], \\
& c=(1-\tau) e^{z} l, \\
& l=\hat{l}(z, \tau, c, g) \\
& q\left(b^{\prime}, z\right) \geq \underline{q} \text { if } b^{\prime}>b,
\end{aligned}
$$

where $b^{\prime}-(1-\delta) b$ denotes current debt issuances, $q$ denotes the price of a bond at the end of a period, and $\hat{l}$ denotes the equilibrium labor hours supplied by households (which solves problem $6)$.

The government cannot issue debt if it remains in default but continues to decide the tax rate and the level of government expenditures. The value function when the government is in default satisfies the following functional equation:

$$
V^{D}(b, z)=\max _{c \geq 0, g \geq 0, \tau \geq 0} u(c, g, 1-l)+\beta \mathbb{E}_{z^{\prime} \mid z}\left[(1-\xi) V^{D}\left(b(1+r), z^{\prime}\right)+\xi V\left(\alpha b(1+r), z^{\prime}\right)\right]
$$

subject to

$$
\begin{aligned}
& g=\tau\left[e^{z}-\phi(z)\right] l, \\
& c=(1-\tau)\left[e^{z}-\phi(z)\right] l, \\
& l=\hat{l}\left(\log \left(e^{z}-\phi(z)\right), \tau, c, g\right) .
\end{aligned}
$$

The assumption that bond holders price bonds in competitive markets implies that

$$
q\left(b^{\prime}, z\right)(1+r)=\mathbb{E}_{z^{\prime} \mid z}\left[\hat{d}\left(b^{\prime}, z^{\prime}\right) q^{D}\left(b^{\prime}, z^{\prime}\right)+\left[1-\hat{d}\left(b^{\prime}, z^{\prime}\right)\right]\left[1+(1-\delta) q\left(\hat{b}\left(b^{\prime}, z^{\prime}\right), z^{\prime}\right)\right]\right],
$$

where $\hat{d}$ denotes the government's default strategy and takes a value of 1 when the government defaults and a value of 0 when it pays, $q^{D}$ denotes the price of a bond in default, and $\hat{b}$ denotes the debt policy rule. The price of a bond in default is given by

$$
\begin{aligned}
q^{D}\left(b^{\prime}, z\right)(1+r)= & \mathbb{E}_{z^{\prime} \mid z}\left[(1-\xi)(1+r) q^{D}\left(b^{\prime}(1+r), z^{\prime}\right)\right. \\
& \left.+\xi \alpha\left[d^{\prime} q^{D}\left(\alpha b^{\prime}, z^{\prime}\right)+\left(1-d^{\prime}\right)\left[1+(1-\delta) q\left(b^{\prime \prime}, z^{\prime}\right)\right]\right]\right],
\end{aligned}
$$


where $d^{\prime}=\hat{d}\left(\alpha b^{\prime}, z^{\prime}\right)$, and $b^{\prime \prime}=\hat{b}\left(\alpha b^{\prime}, z^{\prime}\right)$.

\subsection{Equilibrium definition for the no-rule benchmark}

A Markov Perfect Equilibrium is characterized by

1. a set of value functions $V, V^{R}$, and $V^{D}$,

2. rules for default $\hat{d}$, borrowing $\hat{b}$, government expenditure $\left\{\hat{g}^{R}, \hat{g}^{D}\right\}$, taxes $\left\{\hat{\tau}^{R}, \hat{\tau}^{D}\right\}$, and consumption $\left\{\hat{c}^{R}, \hat{c}^{D}\right\}$,

3. a bond price function $q$,

such that:

(a) given a bond price function $q$; the policy functions $\hat{d}, \hat{b}, \hat{g}^{R}, \hat{g}^{D}, \hat{\tau}^{R}, \hat{\tau}^{D}, \hat{c}^{R}, \hat{c}^{D}$; and the value functions $V, V^{R}$, and $V^{D}$ solve the Bellman equations (7), (8), and (10).

(b) given $\hat{d}$ and $\hat{b}$, the bond price function $q$ satisfies equation (11).

\subsection{Fiscal rules}

We model fiscal rules as limits to either the debt level or the maximum sovereign premium the government can pay when it increases its debt level. An economy with a debt limit rule features an additional constraint $b^{\prime} \leq \bar{b}$ on the functional equation (8).

Since imposing a maximum sovereign premium is equivalent to imposing a minimum sovereign bond price, the sovereign premium limit simply entails increasing the minimum price at which the government can sell bonds while increasing its debt level $(\underline{q})$ in equation (9). ${ }^{12}$ Note that $\underline{q}$ only limits the price at which the government can sell bonds while increasing its debt level. Therefore, the government can still issue at a price lower than $\underline{q}$ up to $\delta b$ bonds. This is, the government can

\footnotetext{
${ }^{12}$ In order to compute the sovereign premium implicit in a bond price, we first compute the yield $i$ an investor
} 
always roll over debt payments that are due this period. Furthermore, even when the government does not issue debt priced lower than $\underline{q}$, the price of debt issued in previous periods may be lower than $q$. Thus, one can observe sovereign premiums higher than the limit targeted in the fiscal rule.

\section{Benchmark calibration}

Table 1 presents the benchmark calibration. A period in the model refers to a quarter. We use a peripheral European economy (Spain) to discipline the parameter values corresponding to the sovereign borrower. Aguiar and Gopinath (2007) show that the cyclical behavior of the Spanish economy resembles that of small open developing economies. As Hatchondo et al. (2010), we solve the model numerically using value function iteration and interpolation. ${ }^{13}$

We estimated equation (5) using quarterly real GDP data from Spain for the period from the first quarter of 1960 to the first quarter of 2013. As in Cuadra et al. (2010), we assumed that preferences are described by the following function:

$$
u(c, g, l)=\pi \frac{g^{1-\gamma_{g}}}{1-\gamma_{g}}+(1-\pi) \frac{\left[c-\psi l^{1+\omega} /(1+\omega)\right]^{1-\gamma}}{1-\gamma} .
$$

We assumed that domestic households have a coefficient of relative risk aversion on private consumption $(\gamma)$ of 2 . The inverse of the labor elasticity $(\omega)$ and the weight of labor hours on the utility $(\psi)$ are taken from Neumeyer and Perri (2005), who study business cycles in small open economies. As explained below, the weight of public consumption in the utility $(\pi)$ and the risk aversion for public consumption $\left(\gamma_{g}\right)$ are calibrated to fit targets from the data.

would earn if it holds the sovereign bond to maturity (forever) and no default is declared. This yield satisfies

$$
q_{t}=\sum_{j=1}^{\infty} \frac{(1-\delta)^{j-1}}{(1+i)^{j}} .
$$

The sovereign premium is the difference between the yield $i$ and the risk-free rate $r$.

${ }^{13} \mathrm{We}$ use linear interpolation for endowment levels and spline interpolation for asset positions. The algorithm finds two value functions, $V^{R}$ and $V^{D}$, and the bond price $q$. We solve for the equilibrium of the finite-horizon version of the economy, and we increase the number of periods of the finite-horizon economy until value functions and bond prices for the first and second periods of this economy are sufficiently close. We then use the first-period equilibrium functions as an approximation of the infinite horizon-economic equilibrium functions. 


\begin{tabular}{lcccc}
\hline \hline Domestic income autocorrelation coefficient & $\rho$ & 0.97 & Spain 1960Q1-2013Q1 \\
Standard deviation of domestic innovations & $\sigma_{\epsilon}$ & $1.04 \%$ & Spain 1960Q1-2013Q1 \\
Mean productivity & $\mu_{y}$ & $(-1 / 2) \sigma_{\epsilon}^{2}$ & Mean productivity level $=1$ \\
Risk aversion of private consumption & $\gamma$ & 2 & Prior literature \\
Inverse of labor elasticity & $\omega$ & 0.6 & Neumeyer and Perri (2005) \\
Weight of labor hours & $\psi$ & $2.48 /(1+\omega)$ & Neumeyer and Perri (2005) \\
Recovery rate of debt in default & $\alpha$ & 0.35 & Cruces and Trebesch (2013) \\
Minimum issuance price without fiscal rule & $\underline{q}$ & 0.3 & Never binding in simulations \\
Risk-free rate & $r$ & 0.01 & Prior literature \\
Duration of defaults & $\xi$ & 0.083 & Calibrated to fit targets \\
Discount factor & $\beta$ & 0.97 & Calibrated to fit targets \\
Duration of long-term bond & $\delta$ & 0.0275 & Calibrated to fit targets \\
Income loss while in default & $\lambda_{0}$ & -0.731 & Calibrated to fit targets \\
Income loss while in default & $\lambda_{1}$ & 0.9 & Calibrated to fit targets \\
Risk aversion of public consumption & $\gamma_{g}$ & 3 & Calibrated to fit targets \\
Weight of public consumption & $\pi$ & 0.182 & Calibrated to fit targets \\
\hline \hline
\end{tabular}

Table 1: Parameter values. 
We assume an annual risk-free rate of 4 percent, which is standard in the literature. The recovery rate of debt in default $(\alpha)$ is assumed to take a value of 0.35 . This is the average recovery rate reported by Cruces and Trebesch (2013) for debt restructurings with a reduction in the face value (we find that in the simulations, the government chooses to exit a default every time it has the opportunity of doing so).

We assume that the minimum issuance price for long-term debt (q) equals $30 \%$ of the mean default-free price of long-term bonds. This constraint is not binding in the simulations. The yield to maturity implied by the assumed value of $\underline{q}$ is higher than the maximum yield to maturity at which any European government issued debt since 2008 (see Trebesch and Wright, 2013). ${ }^{14}$

As in Arellano (2008) and Chatterjee and Eyigungor (2012), we assume that it is proportionally more costly to default in good times. They show that this property is important in accounting for the dynamics of the sovereign debt interest rate spread. Mendoza and Yue (2012) show that this property of the cost of defaulting arises endogenously in a setup in which defaults affect the ability of local firms to acquire a foreign intermediate input good. Thus, we assume that $\phi(z) / \exp (z)$ is increasing in $z$. In particular, we assume a quadratic TFP loss function during a default episode $\phi(z)=\max \left\{\lambda_{0} e^{z}+\lambda_{1} e^{2 z}, 0\right\}$.

There are seven remaining parameter values that we calibrated to match seven moments in the data from Spain between 2008 and 2013: the probability with which a government can exit a default $(\xi)$, the rate of decay of coupon obligations $(1-\delta)$, the two parameters that define the productivity cost of defaulting $\left(\lambda_{0}, \lambda_{1}\right)$, the discount factor $(\beta)$, the weight of public consumption in the utility $(\pi)$, and the risk aversion for public consumption $\left(\gamma_{g}\right)$. These are all calibrated to match: (i) the average time a defaulting government remains excluded from capital markets, (ii) the average duration of government debt, (iii) the level of government debt, (iv) the average long-term interest rate spread, (v) the volatility of private consumption relative to the volatility of income, (vi) the ratio of government consumption to private consumption $(g / c)$, and (vii) the volatility of government consumption relative to the volatility of income. We target an average exclusion from capital markets of three years after a default. This is the estimate obtained by Dias and Richmond (2007) for the median duration of exclusion using their partial access definition of

\footnotetext{
${ }^{14}$ We thank Christoph Trebesch and Mark Wright for sharing their data with us.
} 
re-entry. ${ }^{15}$ A three-year exclusion period is also within the range of estimates reported by Gelos et al. (2011). For the last six targets, we use data from Spain from 2008 to 2013. We chose this period because the interest rate spread paid by the Spanish government was around zero between 1999 and 2007, and before the introduction of the euro the Spanish government issued debts denominated in local currency.

\section{Results}

For simplicity, we first study the effects of introducing fiscal rules in economies that initially are not indebted. We later present results for indebted economies. This section is organized as follows. First, we show that the benchmark model (without rules) can mimic salient features of business cycles in emerging economies. Secondly, we show that a government can benefit from committing to a debt or spread limit. Thirdly, we show that debt limits are not robust: imposing a debt limit that is optimal for the benchmark calibration may fail to produce welfare gains in other economies. Fourthly, we show that in contrast to the optimal debt limit for the benchmark economy, the optimal spread limit for the benchmark economy still produces welfare gains in other economies. Fifthly, we discuss whether fiscal rules should allow for larger fiscal deficits in bad times (allowing room for more countercyclical fiscal policies). Sixthly, we show that assuming that the government is shortsighted implies stricter fiscal rules and larger welfare gains. Seventhly, we show that the gains from imposing fiscal rules may be even larger for indebted economies. Eighthly, we discuss a no-default fiscal rule.

\subsection{Simulations without a fiscal rule}

Table 2 shows that the model without a fiscal rule well approximates moments in the data. Since there has not been a sovereign default in Spain in recent years, we report results for simulated sample paths without defaults. We report the mean of the value of each moment in 1,000

\footnotetext{
${ }^{15}$ According to Dias and Richmond's (2007) definition of partial market access, a sovereign in default is said to regain access to capital markets in the first year in which there are positive transfers (in the form of bond or commercial bank loans) to the domestic public or private sector.
} 


\begin{tabular}{lcc}
\hline \hline & Spain & Benchmark \\
\hline Debt / mean annual income (in \%) & 61.8 & 61.5 \\
Debt duration (years) & 6.0 & 6.0 \\
Annual spread (in \%) & 2.0 & 2.0 \\
Mean g/c (in \%) & 36.5 & 36.5 \\
$\sigma(g) / \sigma(y)$ & 0.9 & 0.9 \\
$\sigma(c) / \sigma(y)$ & 1.1 & 1.1 \\
\hline \hline
\end{tabular}

Table 2: Simulations without a fiscal rule. The standard deviation of a variable $x$ is denoted by $\sigma(x)$. The second column is computed using data from Spain. The logarithm of private consumption $(c)$ and income $(y)$ were de-trended using the Hodrick-Prescott filter, with a smoothing parameter of 1600 . We report deviations from the trend. The debt level in the simulations is calculated as the present value of future payment obligations discounted at the average risk-free rate, i.e., $b(\delta+r)^{-1}$. We report the annualized spread.

simulation samples. We take the last 74 periods (quarters) of samples in which no default occurs in the last 100 periods.

Figure 1 shows that it is optimal for the government to choose a pro-cyclical fiscal policy. That is, when aggregate output is lower, the tax rate tends to be higher, and the level of public good provision tends to be lower. When income is low, borrowing is more costly because it increases the probability of default (and future default decisions are not optimal from an ex-ante perspective). Thus, the government borrows less, increases the tax rate, and lowers expenditures. This is consistent with data from Spain (including fiscal adjustment during the current crisis) and other small open economies. For instance, Végh and Vuletin (2011) finds that the three industrial countries in their sample with the most pro-cyclical fiscal policies are Spain, Portugal, and Greece, all countries facing significant sovereign risk.

\section{$5.2 \quad$ Fiscal rules}

In this subsection we discuss the optimal debt-limit and spread-limit fiscal rules for our benchmark economy. That is, we search for the fiscal rule that maximizes welfare when imposed on a no-rule economy with the benchmark parameterization. We assume there is no initial debt, and 

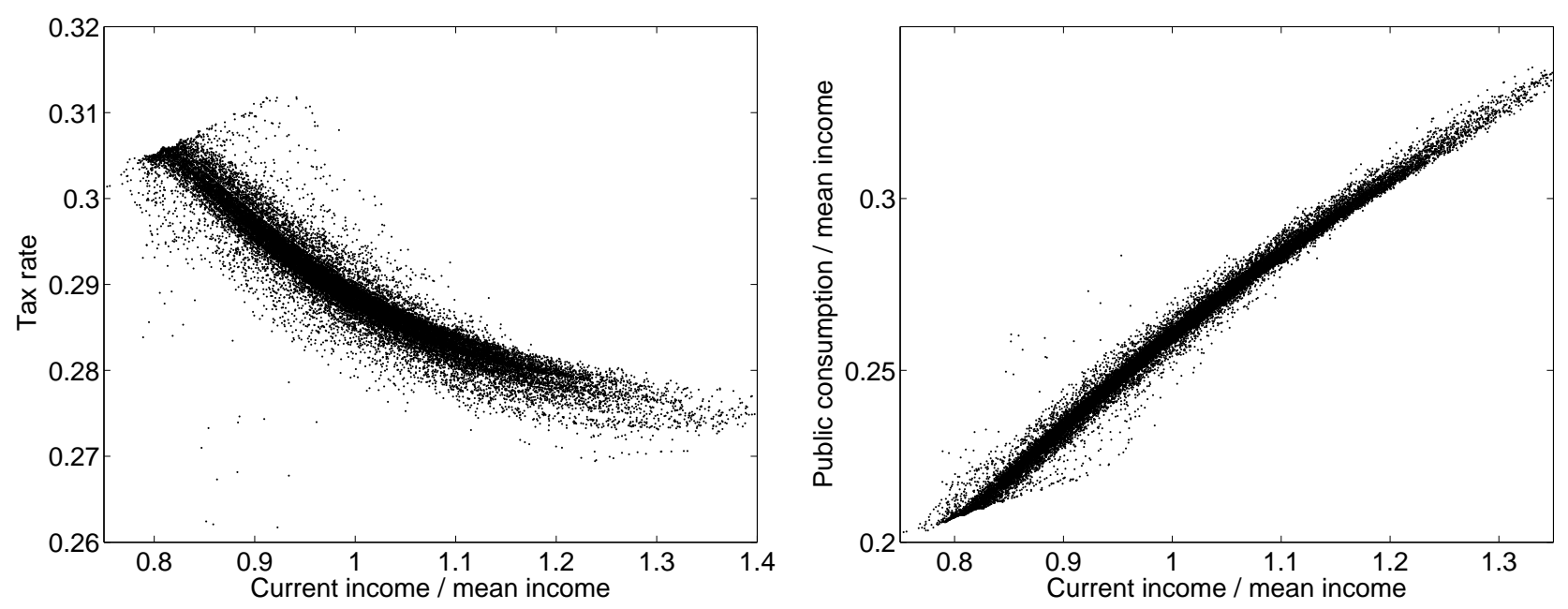

Figure 1: Procyclical fiscal policy.

that TFP is at its unconditional mean.

We find that the optimal debt ceiling is equal to 52.5 percent of the mean annual output in the benchmark no-rule economy. The optimal spread limit is 0.45 percent. That is, the government cannot increase its debt level while paying a sovereign premium higher than 0.45 percent. Table 3 shows that the preferred debt and spread limits reduce the default frequency and, consequently, the sovereign spread.

As discussed in Section 2, the government benefits from implementing a fiscal rule because it mitigates the debt dilution problem. Figure 2 illustrates how a fiscal rule creates new borrowing opportunities for a government. On the one hand, the fiscal rule limits the amount the government can promise to pay (i.e., its debt level). On the other hand, the rule also limits future borrowing, enabling the government to pay a lower interest rate for any chosen debt level.

Table 3 shows that imposing a spread-limit rule produces welfare gains comparable to those entailed by imposing a debt limit. For a given economy (i.e., for a given set of parameter values), the difference between the limit to overborrowing imposed by a fixed debt ceiling and the one imposed by a fixed spread ceiling is that the latter is a state-contingent limit on the debt level. Spreads are higher during economic downturns (when productivity and, thus, the cost of defaulting are lower). Consequently, a spread limit imposes a tighter constraint on debt 


\begin{tabular}{lccc}
\hline \hline & Without rule & Debt rule $(52.5 \%)$ & Spread rule $(0.45 \%)$ \\
\hline Debt / mean annual income (in \%) & 61.5 & 54.9 & 59.4 \\
Annual spread (in \%) & 2.0 & 0.5 & 1.0 \\
Mean g/c (in \%) & 36.5 & 37.1 & 36.9 \\
$\sigma(g) / \sigma(y)$ & 0.9 & 0.9 & 1.0 \\
$\sigma(c) / \sigma(y)$ & 1.1 & 1.1 & 1.1 \\
Defaults per 100 years & 2.9 & 0.8 & 1.1 \\
Welfare gain (in \%) & & 0.5 & 0.4 \\
\hline \hline
\end{tabular}

Table 3: Simulations with fiscal rules. We measure welfare gains as the constant proportional change in consumption of the private good that would leave domestic consumers indifferent between continuing to live in the benchmark economy (without a fiscal rule) and moving to an economy with a fiscal rule.

increases during economic downturns. This difference between debt and spread ceilings could be eliminated by imposing limits that change over the business cycle, as many countries have done (Budina et al., 2012; IMF, 2009; Schaechter et al., 2012). Therefore, we do not want to emphasize this difference (Subsection 5.5 discusses fiscal rules imposing limits that change over the business cycle). We want to emphasize instead the advantages of spread limits arising from their robustness.

\subsection{Robustness of debt limits}

In this subsection, we investigate whether the optimal debt limit for one economy still produces benefits when imposed on another economy with a different level of debt tolerance. This question is important because political constraints may lead to supranational fiscal rules that impose common debt limits across countries (as happened, for instance, with the Maastricht Treaty), and it is well known that countries may have very different levels of debt tolerance. Furthermore, identifying the level of debt tolerance in any economy may be difficult, and this level may change over time. Therefore, one would like policy recommendations to be robust to the level of debt tolerance.

Figure 3 shows that the 52.5 percent debt limit that maximizes welfare in the benchmark 


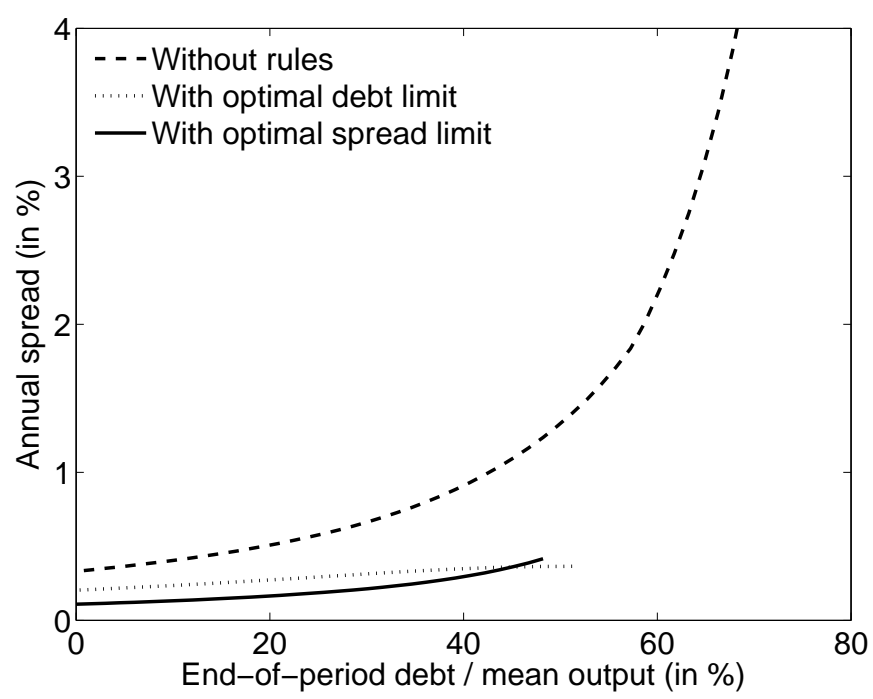

Figure 2: Annualized spread asked by lenders for different levels of debt. The figure assumes the average TFP shock.

economy may fail to produce welfare gains in economies with different levels of debt tolerance. We change the assumed level of debt tolerance in two ways: (i) we increase the average number of years a government is excluded from capital markets (and thus has lower productivity) after defaulting, and (ii) we increase the recovery rate for debt in default. All other parameter values are the ones in the benchmark parameterization. Increasing the exclusion duration increases the cost of defaulting and thus allows a government to pay a lower interest rate for any debt level. This leads the government to choose higher debt levels. Increasing the recovery rate lowers the lenders' losses after a default, and thus allows the government to pay a lower interest rate for any debt level and also leads it to choose higher debt levels. Figure 4 shows that indeed, as the exclusion duration or the recovery rate go up, the average debt level increases and the average spread decreases. The figure shows that, overall, we are studying economies with average debt levels between 30 and 90 percent of average trend output and average sovereign spread levels between 1.5 and 2.8 percent. This covers a range of plausible parameterizations of the model for peripheral European economies. ${ }^{16}$

\footnotetext{
${ }^{16}$ In previous working paper versions of this study, we presented variations of the model (e.g., endowment economies and zero recovery rates after default) and parameterizations that are more appropriate to emerging economies (with the baseline calibration targeting data from Argentina before the 2001 default and thus featuring
} 

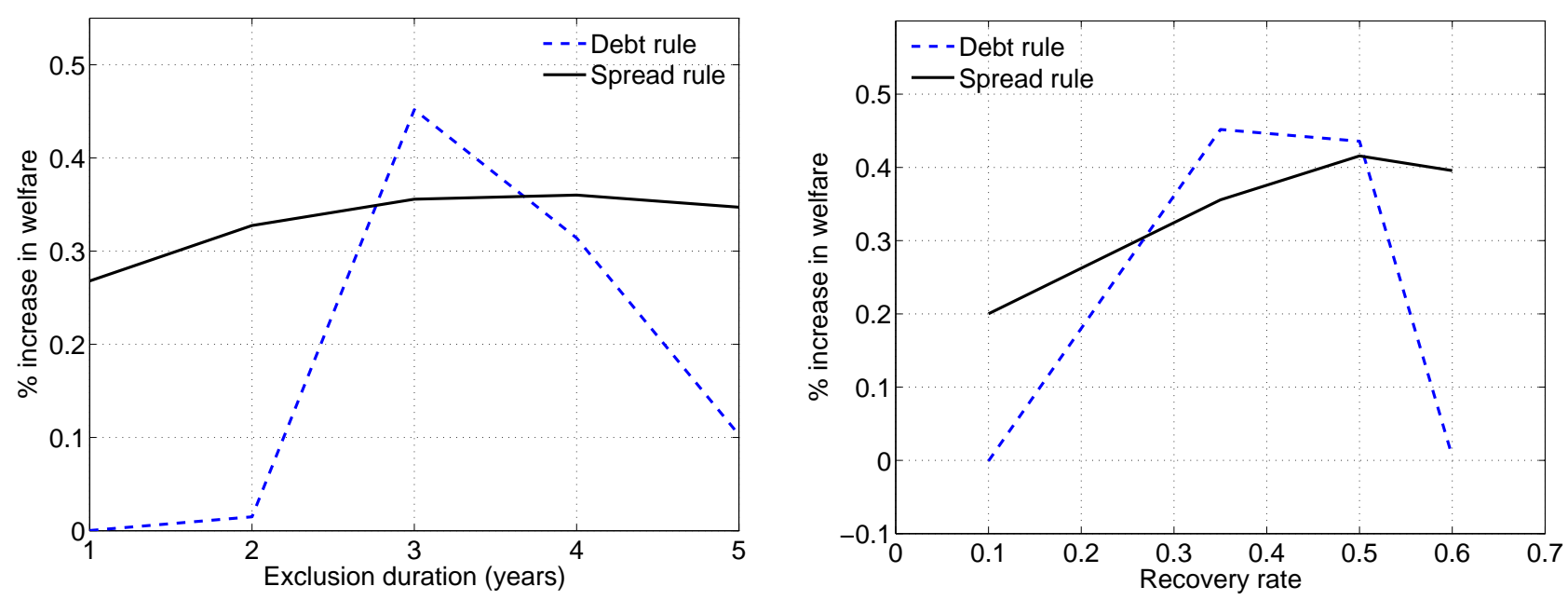

Figure 3: Welfare gains from imposing the same fiscal rule in economies with different levels of debt tolerance. The debt rule is a debt limit equal to 52.5 percent of the mean level of annual income. The spread rule does not allow the government to increase its debt level while paying a sovereign spread higher than 0.45 percent. The exclusion duration is the average number of years a government is excluded from capital markets after defaulting.

Intuitively, in economies with very low debt tolerance the 52.5 percent debt limit is rarely binding and thus does not have significant effects. In contrast, in economies with very high debt tolerance the 52.5 percent debt limit may be too tight, lowering welfare gains and, for sufficiently high levels of debt tolerance, creating welfare losses. Indeed, Figure 4 shows that the optimal debt limit increases with the assumed level of debt tolerance. Thus, while the results in Subsection 5.2 illustrate the potential benefits from imposing debt limits, this subsection illustrates the risks of imposing a constant debt limit over time or across countries.

\subsection{Robustness of spread limits}

Figure 3 shows that, in contrast with the optimal debt limit for the benchmark economy, the optimal spread limit for the benchmark economy produces substantial welfare gains when imposed on economies with different levels of debt tolerance. Figure 4 further illustrates the greater robustness of spread limits. The figure shows that the economies with different debt tolerance

an average sovereign spread of 7.4 percent). We there showed that fiscal rules limiting the sovereign premium are more robust than those limiting debt levels. 

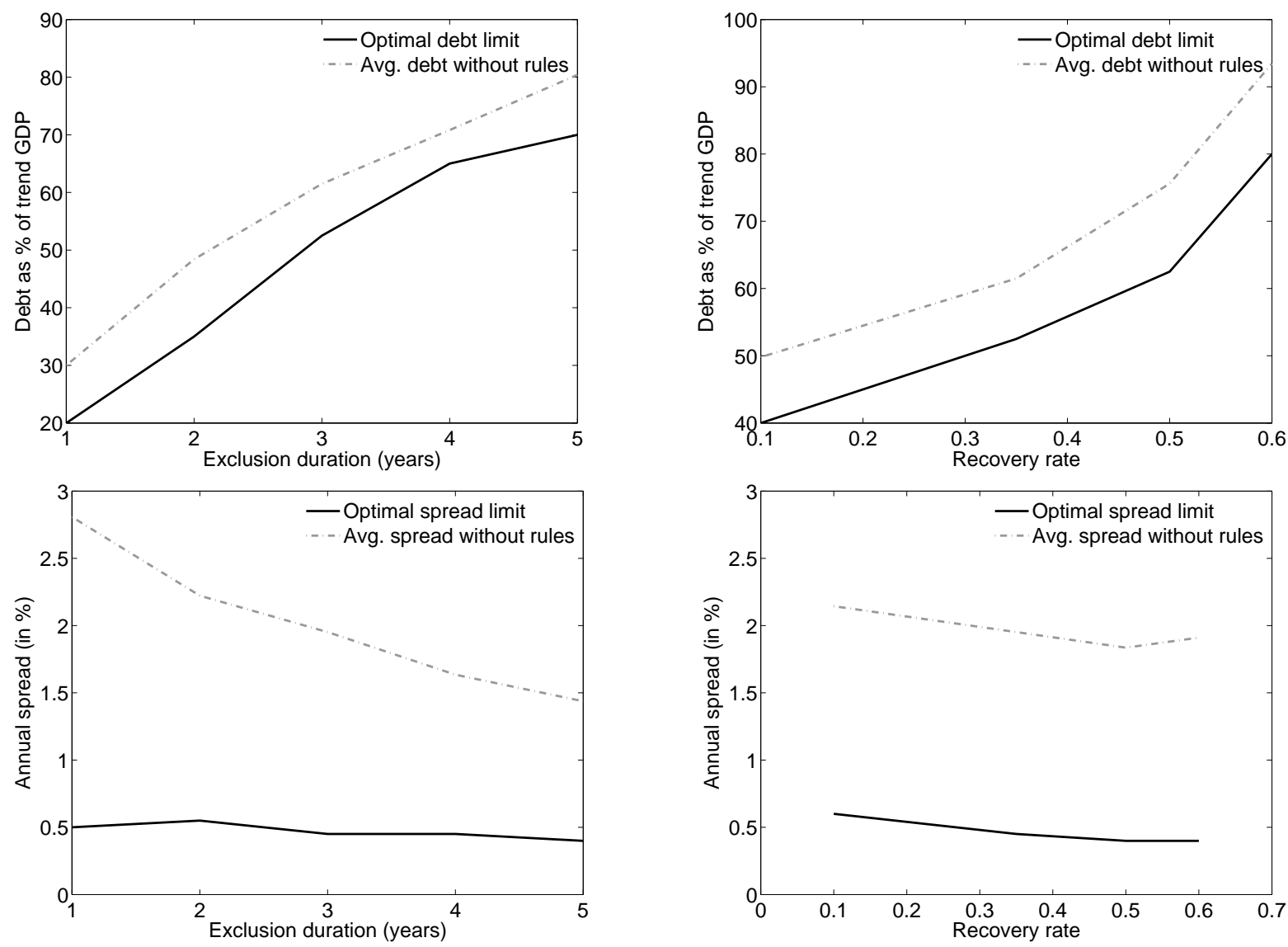

Figure 4: Average debt and spread levels and optimal debt and spread limits in economies with different levels of debt tolerance. The exclusion duration is the average number of years a government is excluded from capital markets after defaulting.

that we are studying differ greatly in the average spread observed without a fiscal rule: the average spread in the lowest-tolerance economy is 1.3 percentage points higher than that in the highest tolerance economy. However, the optimal spread limit is close to 0.5 percent for all these economies. This shows a crucial difference between fiscal rules targeting debt and spread levels.

It is intuitively clear why spread limits are more robust than debt limits. Default risk imposes on a government endogenous borrowing constraints. The government benefits from higher debt levels as long as these levels do not imply higher sovereign risk. Gains from imposing fiscal rules arise because, by mitigating the debt dilution problem, such rules lower sovereign risk. Spread 
limits attack excessive sovereign risk directly. In contrast, since optimal debt limits attack excessive sovereign risk indirectly by targeting directly debt levels, they are highly dependent on the level of debt tolerance (i.e., on the level of debt consistent with low levels of sovereign risk in each economy).

\subsection{Fiscal rules and the cyclicality of fiscal policy}

We next discuss whether fiscal rules should allow for a larger government deficit in bad times. This is a central issue in discussions of fiscal rules in policy circles. Our analysis allows us to shed light on the desirability of "escape clauses" that soften fiscal rules during recessionary periods. These clauses are a component of many fiscal rules and are often implemented with the assistance of independent fiscal bodies (Budina et al., 2012; IMF, 2009; Schaechter et al., 2012). Our findings serve as a warning against promoting these clauses in the presence of sovereign risk: promoting a countercyclical fiscal policy reduces the volatility of consumption but does so at the cost of increasing default risk.

We focus on rules imposing debt limits. Since the sovereign spread changes with the state of the economy, focusing on debt limits instead of spread limits renders more transparent the discussion of how the limit imposed by the rule should be allowed to change over the business cycle. As in previous subsections, for simplicity, we focus on an economy that initially is not indebted.

We assume that the government can commit to a debt limit that is a linear function of the current total factor productivity shock (assuming that the debt limit is a function of output instead of productivity would allow the government to manipulate the limit with the tax rate, complicating the interpretation of the results):

$$
\underline{b}(z)=\bar{y}\left[a_{0}+a_{1}\left(e^{z}-e^{\mu_{z}}\right)\right],
$$

where $\bar{y}$ is the average output level in the simulations of the benchmark economy. We search for the optimal coefficients of the debt limit specified in equation (12).

We find that for the benchmark calibration the best rule does not allow the debt limit to change over the business cycle: the optimal debt limit is the one discussed in Subsection 5.2, 


\begin{tabular}{lccc}
\hline \hline & $a_{1}=-1$ & $a_{1}=0$ & $a_{1}=1$ \\
\hline Debt / mean annual income (in \%) & 53.3 & 54.9 & 54.0 \\
Annual spread (in \%) & 0.8 & 0.5 & 0.4 \\
Mean g/c (in \%) & 37.0 & 37.1 & 37.2 \\
$\sigma(g) / \sigma(y)$ & 0.8 & 0.9 & 1.1 \\
$\sigma(c) / \sigma(y)$ & 1.0 & 1.1 & 1.1 \\
Defaults per 100 years & 1.2 & 0.8 & 0.6 \\
Welfare gain (in \%) & 0.2 & 0.5 & 0.4 \\
\hline \hline
\end{tabular}

Table 4: Simulation results with a debt limit $\underline{b}(z)=\bar{y}\left[a_{0}+a_{1}\left(e^{z}-e^{\mu_{z}}\right)\right]$, for $a_{0}=2.1$.

which corresponds to $a_{1}=0$ and $a_{0}=2.1$. Table 4 presents business cycle statistics from simulations of economies with rules that include an average limit of 52.5 percent and allow the limit to change with the current total productivity shock. The table shows that a fiscal rule that better accommodates a more countercyclical fiscal policy by allowing the debt limit to increase during economic downturns $\left(a_{1}=-1\right)$ will be successful in reducing the volatility of public and private consumption. However, this occurs at the expense of increasing the default frequency (in spite of the average debt level being lower). Since the cost of defaulting is lower during economic downturns (as reflected in countercyclical sovereign spreads), having higher debt levels during downturns imply a higher default frequency. Allowing for lower debt ceilings during downturns $\left(a_{1}=1\right)$ has the opposite effects, i.e., it reduces the default frequency at the expense of increasing the consumption volatility.

Subsection 5.1 shows that in the presence of default risk, it may be optimal for a government to sequentially choose a pro-cyclical fiscal policy. This subsection goes further, showing that, even when the government can limit future policy choices with a fiscal rule, it may not want to use this rule to promote a countercyclical policy. 


\subsection{Shortsighted governments}

In this subsection, we discuss the extent to which our findings would change if we assumed that governments are shortsighted. Shortsighted governments (for instance, because of political polarization or turnover) are typically mentioned as a justification for fiscal rules. We have already shown that fiscal rules can be beneficial even in the absence of shortsighted governments. This subsection shows that assuming shortsighted governments increases the gains to be had by introducing fiscal rules.

To gauge the role of governments' myopia, we assume that the fiscal rule is chosen by a planner who discounts future utility flows with a $\beta$ higher than the one governments use when they choose their fiscal policy. For instance, one may think that the political coalition needed to establish a fiscal rule in the constitution requires a majority that mitigates the effects of political polarization when future outcomes are discounted (for a discussion of the effects of polarization on fiscal dynamics, see Azzimonti, 2011). We repeat the exercise proposed in Subsection 5.2, and find the optimal debt limit when there is no initial debt and the TFP is at its mean level.

Table 5 presents the optimal fiscal rules chosen by planners who are more patient than shortsighted governments. As expected, the rule chosen giving more weight to future periods imposes lower debt limits. The welfare gain from introducing a fiscal rule may be much higher when we assume that the rule corrects the government's myopia.

\begin{tabular}{lcccc}
\hline \hline Planner's discount factor & 0.97 & 0.975 & 0.980 & 0.985 \\
Optimal debt limit (\% of average output in the no-rule economy) & 52.5 & 49.5 & 45.0 & 37.5 \\
Welfare gain (in \%) & 0.5 & 0.5 & 0.6 & 0.9 \\
\hline \hline
\end{tabular}

Table 5: Optimal fiscal rule with shortsighted governments. The government's discount factor is 0.97 in all cases.

\subsection{Indebted economies}

This subsection discusses fiscal rules for indebted economies. We focus on debt-limit rules. Imposing a debt reduction on an indebted economy may imply a costly transition. We show that, 
nevertheless, imposing fiscal rules in indebted economies produces substantial welfare gains. In order to lower the number of rules we have to study, we restrict our attention to rules imposing limits that do not depend on the current productivity shock.

We assume that when the government introduces a fiscal rule it announces that the debt limit $\bar{b}$ will be imposed in every period starting in period $T$. The government's maximization problem is not recursive until $T$. We solve the problem backwards, starting from the first period in which it becomes recursive. We search for the combination of $\bar{b}$ and $T$ that maximizes welfare. Delaying the imposition of fiscal rule targets is a common way of dealing with transitions. For instance, Germany amended its constitution in 2009 to introduce a fiscal rule to be enforced after 2016 for the federal government and after 2020 for regional governments. Similarly, Spain amended its constitution in 2011 to introduce a fiscal rule to be enforced after 2020 .

We assume that the initial debt level is 62 percent of the average output in the benchmark no-rule economy (the average debt level for that economy). We consider different levels of productivity shock for the period in which the rule is introduced.

We find that the initial productivity level does not significantly affect the rule to which the government would like to commit: in all cases welfare is maximized with a debt limit of 60 percent (of the average output in the benchmark no-rule economy), and a transition of 5 (8) quarters when the initial productivity is one standard deviation above (below) the mean. Welfare gains from introducing the fiscal rule are between 0.6 and 0.8 percent, depending on the initial level of TFP.

Figure 5 presents the mean spread level after the optimal rule announcement. The figure shows that the optimal fiscal rule implies a substantial reduction of the spread, even though the debt limit (60 percent) is very close to the initial debt level (62 percent). This happens because part of the cost of defaulting is the loss of access to capital markets, and this cost is higher when capital markets are more attractive. Since the fiscal rule makes capital markets more attractive (by mitigating the debt dilution problem, and thus allowing the government to borrow at a lower rate; Figure 2), the rule increases the cost of defaulting, allowing the government to borrow more (for a given interest rate). Figure 5 also shows that the spread declines immediately with the rule announcement (before any debt reduction takes place), reflecting the expectation of future 
debt reductions. This implies that the level of indebtedness could be reduced without any fiscal sacrifice (by not spending all the resources saved in interest payments).

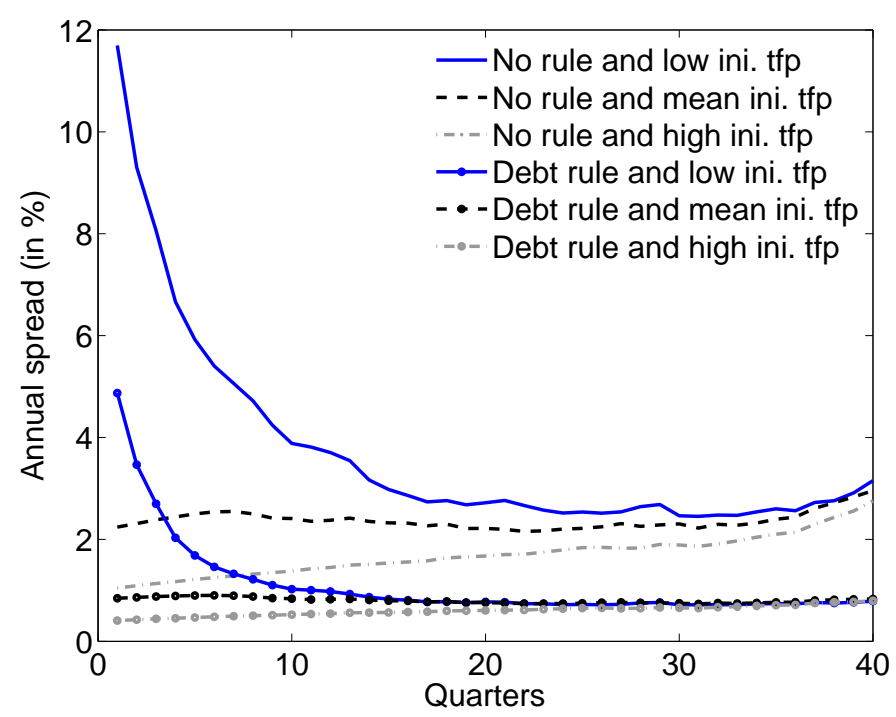

Figure 5: Spread during transitions that follow the announcement of the optimal debt-limit rule, for samples without defaults.

\subsection{A no-default fiscal rule}

In this subsection, we discuss a fiscal rule that would force the government to pay its debt, eliminating sovereign defaults. Since the dynamic inefficiencies that account for the gains to be had from introducing a fiscal rule arise because of default risk, it may seem natural to attack these inefficiencies directly by eliminating the possibility of default. However, we show that a rule that eliminates the possibility of default may be very difficult to enforce, as the temptation of abandoning it would be large. We also show that, in contrast, the temptation to abandon a rule limiting the level of sovereign debt or spread is much smaller. This is consistent with the growing number of countries adopting rules that limit their debt level (both directly and through limits to the fiscal deficit) and the rarity of rules intending to eliminate the possibility of defaulting (the IMF fiscal rule database presents a thorough description of fiscal rules around 
the world; see Budina et al., 2012; IMF, 2009; Schaechter et al., 2012).

In order to study the economy with the no-default fiscal rule, we introduce an exogenous borrowing limit. Recall that in our model borrowing is endogenously limited by the possibility of default. A fiscal rule eliminating this possibility removes this endogenous borrowing constraint, creating the need for an exogenous borrowing limit. In particular, we assume that in the nodefault economy, the government cannot borrow more than fifteen times the low (one standard deviation below the mean) output in the benchmark no-rule economy. Since we strip the model from default risk, there is no difference between short- and long-term debt, and thus we solve and simulate the following problem:

$$
\begin{aligned}
& W(b, z)=\max _{b^{\prime} \geq 0, c \geq 0, g \geq 0, \tau \geq 0}\left\{u(c, g, 1-l)+\beta \mathbb{E}_{z^{\prime} \mid z} W\left(b^{\prime}, z^{\prime}\right)\right\}, \\
& \text { subject to } \\
& g=\tau e^{z} l-b+\frac{b^{\prime}}{1+r}, \\
& c=(1-\tau) e^{z} l, \\
& l=\hat{l}(z, \tau, c, g) \\
& b^{\prime} \leq \bar{b} .
\end{aligned}
$$

We measure the gain that results from deviating from the no-default rule in any period. Once the government so deviates, we assume that it returns to the benchmark economy without rules described in Subsection 3.2.

In order to perform this exercise, we need to make an assumption about the recovery rate for the debt that the government defaults on when it deviates from the no-default rule. It is not obvious which recovery rate would be reasonable for the high debt levels in the no-default economy. For that reason, we solve the model for two recovery rates: zero and 12 percent. We find that this assumption does not change significantly the cost of enforcing the no-default rule. All other parameter values are as in the benchmark calibration. This implies a mean debt level in the simulations that is almost four times annual output. Given such high debt levels, the 12 percent recovery rate already implies a very high post-default debt level. Furthermore, assuming 
a higher recovery rate would force us to solve the default model for a very wide range of debt levels, which would be computationally costly.

We measure the implied cost of enforcing the rule in terms of a one-time TFP loss (which does not affect the distribution of TFP in future periods). We find the TFP loss implied by abandoning the rule that would make the representative household indifferent between keeping the rule and abandoning it. For all states in the simulations of the economy with the fiscal rule, we compute the output loss implied by this TFP decline in the no-rule economy. We express the TFP loss as a fraction of mean annual output.

Formally, we first find the value of abandoning the fiscal rule for any implied one-time TFP $\operatorname{loss} x$

$$
\hat{V}(b, z, x)=\max \left\{\hat{V}^{R}(b, z, x), \hat{V}^{D}(\hat{\alpha} b, z, x)\right\},
$$

where $\hat{\alpha}$ denotes the debt reduction gained by the government in the period in which it deviates from the no-default fiscal rule. ${ }^{17}$ The function $\hat{V}^{R}$ satisfies

$$
\begin{aligned}
& \hat{V}^{R}(b, z, x)=\max _{b^{\prime} \geq 0, c \geq 0, g \geq 0, \tau \geq 0}\left\{u(c, g, 1-l)+\beta \mathbb{E}_{z^{\prime} \mid z} V\left(b^{\prime}, z^{\prime}\right)\right\}, \\
& \text { subject to } \\
& g=\tau x e^{z} l-b+q\left(b^{\prime}, z\right)\left[b^{\prime}-(1-\delta) b\right], \\
& c=(1-\tau) x e^{z} l, \\
& l=\hat{l}(\log (x)+z, \tau, c, g) \\
& b^{\prime}>b \text { only if } q\left(b^{\prime}, z\right) \geq \underline{q} .
\end{aligned}
$$

\footnotetext{
${ }^{17}$ We allow for the possibility of not defaulting after abandoning the fiscal rule because we also compute the cost of enforcing debt-limit and spread-limit fiscal rules (the government always chooses to default after abandoning the no-default rule). The debt reduction obtained when abandoning those rules is zero $(\hat{\alpha}=1)$.
} 
The function $\hat{V}^{D}$ satisfies

$$
\begin{aligned}
& \hat{V}^{D}(b, z, x)=\max _{c \geq 0, g \geq 0, \tau \geq 0} u(c, g, 1-l)+\beta \mathbb{E}_{z^{\prime} \mid z}\left[(1-\xi) V^{D}\left(b(1+r), z^{\prime}\right)+\xi V\left(\alpha b(1+r), z^{\prime}\right)\right] \\
& \text { subject to } \\
& g=\tau x\left[e^{z}-\phi(\hat{z})\right] l, \\
& c=(1-\tau) x\left[e^{z}-\phi(\hat{z})\right] l, \\
& l=\hat{l}\left(\log (x)+\log \left(e^{z}-\phi(z)\right), \tau, c, g\right) .
\end{aligned}
$$

Then, for each $(b, z)$ in the simulations of the economy with the no-default fiscal rule, we find the value of $x$ that makes the representative household indifferent between continuing with the fiscal rule and abandoning it (this is, for the no-default rule, we find $x$ such that $W(b, z)=\hat{V}(b, z, x)$ ).

We find that the cost of enforcing the no-default rule would be large: the maximum cost of abiding by the rule and continuing to repay the debt is equivalent to a loss of between 12.3 and 12.4 percent of annual output, depending on the assumed debt reduction obtained by the defaulting government $\hat{\alpha}$. The median welfare loss is between 11.5 and 11.6 percent. This is intuitive. If a no-default rule removes the borrowing constraint implied by the default risk, a government eager to borrow would accumulate a high level of debt, for which the temptation of abandoning the rule and defaulting would be large. Therefore, it is difficult to imagine that a government could credibly commit to a no-default rule.

In contrast, the temptation of abandoning a fiscal rule limiting either the sovereign debt or spread level is much smaller, if it exists at all. We repeat the exercise described above for the 52.5 percent debt limit and a 0.45 percent spread limit (the optimal limits found in Subsection 5.2). We find that the maximum cost of abiding by these rules is negative (equivalent to a -3.4 percent output loss for the debt-limit rule and a -1.4 percent loss for the spread-limit rule). That is, the government would never want to abandon these rules and go back to the no-rule economy.

The government would be willing to abandon the debt-limit or spread-limit fiscal rule if it could credibly introduce these rules again soon enough. Nevertheless, the temptation to do so is still relatively small. For instance, the maximum cost of abiding by these rules instead of abandoning them and then reinstating them after one quarter is equivalent to a loss of 1.0 
percent of annual output for the debt-limit rule and a 1.1 percent loss for the spread-limit rule (the median cost remains negative and is equivalent to a -0.1 percent output loss for both rules). In contrast, even a one-quarter deviation from the no-default fiscal rule would result in a large welfare gain, as it would be enough to benefit from a debt reduction.

\section{Conclusions}

We use a sovereign default framework to show that there may be substantial gains from committing to fiscal rules. We also argue that fiscal rules targeting the level of the sovereign default premium may be preferable over rules targeting sovereign debt levels (as do most fiscal rules presently in force). When we vary parameter values that affect the degree of debt tolerance, the debt limit that maximizes welfare for one parameterization may fail to produce welfare gains for other parameterizations. In contrast, the same sovereign-premium limit produces welfare gains across parameterizations. This is intuitive. While sovereign-premium limits directly attack the government's excessive exposure to sovereign risk, debt limits attack this problem indirectly, and at the risk of imposing excessively low debt levels or being too loose and thus innocuous. Since levels of debt tolerance are difficult to identify, and seem to vary greatly both across countries and over time, fiscal rules targeting the sovereign premium are likely to perform better than rules targeting the debt level. We also show that rules should not necessarily promote a countercyclical fiscal policy.

The advantages of sovereign-spread-limit fiscal rules over the debt-limit fiscal rules discussed in this paper resemble the advantages of interest-rate monetary policy rules over monetaryaggregate policy rules that motivated changes in monetary policy implementation in recent decades. It is well-understood that implementing monetary policy by setting objectives for interest rates may be preferable to doing so by setting objectives for monetary aggregates, in part because of the unstable relationship between monetary aggregates and interest rates. At the core of the greater robustness of sovereign spread-limit fiscal rules versus debt-limit fiscal rules discussed in this paper is the unstable relationship between levels of sovereign debt and spreads.

There are several interesting issues concerning the practical implementation of a sovereign 
spread-targeting fiscal rule that are beyond the scope of this paper. For instance, which sovereign spread should a fiscal rule target? Should the rule target a "core" spread that is less affected by global factors (for instance, the difference between the local sovereign spread and a EMBI-like spread index)? When the spread is above the rule limit, should the government be allowed to rollover debt or should it be forced to reduce its debt level? How much debt should a government be allowed to rollover? Our analysis suggests that spread-targeting fiscal rules are worth considering and, thus, answering these questions should be promising avenues for future research. 


\section{References}

Adler, G. and Sosa, S. (2013). 'Debt Sustainability in Latin America: How Dependent on External Conditions?' IMF Working Paper.

Aguiar, M. and Gopinath, G. (2006). 'Defaultable debt, interest rates and the current account'. Journal of International Economics, volume 69, 64-83.

Aguiar, M. and Gopinath, G. (2007). 'Emerging markets business cycles: the cycle is the trend'. Journal of Political Economy, volume 115, no. 1, 69-102.

Arellano, C. (2008). 'Default Risk and Income Fluctuations in Emerging Economies'. American Economic Review, volume 98(3), 690-712.

Arellano, C. and Ramanarayanan, A. (2010). 'Default and the Maturity Structure in Sovereign Bonds'. Mimeo, University of Minnesota.

Athreya, K., Tam, X. S., and Young, E. R. (2007). 'Does Rising Income Risk Lead to Better Risk Sharing?' Manuscript, University of Virginia.

Azzimonti, M. (2011). 'Barriers to Investment in Polarized Societies'. American Economic Review, volume 101, 2182-2204. 5.

Azzimonti, M., Battaglini, M., and Coate, S. (2010). 'On the Case for a Balanced Budget Amendment to the U.S. Constitution'. Mimeo, Princeton University.

Beetsma, R. and Debrun, X. (2007). 'The new stability and growth pact: A first assessment'. European Economic Review, volume 51, 453-477.

Beetsma, R. and Uhlig, H. (1999). 'An Analysis of the Stability and Growth Pact'. The Economic Journal, volume 109(458), 546-571.

Benjamin, D. and Wright, M. L. J. (2008). 'Recovery Before Redemption? A Theory of Delays in Sovereign Debt Renegotiations'. Manuscript. 
Bi, H. (2011). 'Sovereign default risk premia, fiscal limits and fiscal policy'. European Economic Review. Forthcoming.

Bi, H. and Leeper, E. (2012). 'Analyzing fiscal sustainability'. Working Paper.

Bianchi, J., Hatchondo, J. C., and Martinez, L. (2012). 'International Reserves and Rollover Risk'. NBER Working Paper 18628.

Blanchard, O. (2011). 'Rewriting the Macroeconomists' Playbook in the Wake of the Crisis'. IMFdirect.

Blanchard, O., Dell'Ariccia, G., and Mauro, P. (2010). 'Rethinking Macroeconomic Policy'. IMF Staff Position Note 10/03.

Boz, E. (2011). 'Sovereign Default, Private Sector Creditors, and the IFIs'. Journal of International Economics, volume 83, 70-82.

Budina, N., Kinda, T., Schaechter, A., and Weber, A. (2012). 'Fiscal Rules at a Glance: Country Details from a New Dataset'. IMF Working Paper 12/273.

Calvo, G. (1988). 'Servicing the Public Debt: The Role of Expectations'. The American Economic Review, volume 78 (4), 647-661.

Chatterjee, S., Corbae, D., Nakajima, M., and Ríos-Rull, J.-V. (2007). 'A Quantitative Theory of Unsecured Consumer Credit with Risk of Default'. Econometrica, volume 75, 1525-1589.

Chatterjee, S. and Eyigungor, B. (2012). 'Maturity, Indebtedness and Default Risk'. American Economic Review. Forthcoming.

Chatterjee, S. and Eyigungor, B. (2013). 'Debt Dilution and Seniority in a Model of Defaultable Sovereign Debt'. Federal Reserve Bank of Philadelphia Working Paper 13-30.

Claessens, S., Mody, A., and Vallée, S. (2012). 'Paths to Eurobonds'. IMF Working Paper $12 / 172$. 
Corbacho, A. and Schwartz, G. (2007). 'Fiscal Responsibility Laws'. in Promoting Fiscal Discipline, volume Ter-Minassian, T. and M. S. Kumar (eds.).

Cruces, J. J. and Trebesch, C. (2013). 'Sovereign Defaults: The Price of Haircuts'. American Economic Journal: Macroeconomics, volume 5(3), 85-117.

Cuadra, G., Sanchez, J. M., and Sapriza, H. (2010). 'Fiscal policy and default risk in emerging markets'. Review of Economic Dynamics, volume 13(2), 452-469.

Cuadra, G. and Sapriza, H. (2008). 'Sovereign default, interest rates and political uncertainty in emerging markets'. Journal of International Economics, volume 76, 78-88.

Debrun, X. and Kumar, M. S. (2007). 'Fiscal Rules, Fiscal Councils and All That: Commitment Devices, Signaling Tools or Smokescreens?' in Fiscal Policy: Current Issues and Challenges, volume Banca dItalia (eds.).

Debrun, X., Moulin, L., Turrini, A., Ayuso-i Casals, J., and Kumar, M. S. (2008). 'Tied to the mast? National fiscal rules in the European Union'. Economic Polic, volume 23(54), 297-362.

D’Erasmo, P. (2011). 'Government Reputation and Debt Repayment'. Manuscript.

Deroose, S., Moulin, L., and Wierts, P. (2006). 'National expenditure rules and expenditure outcomes: Evidence for EU member states'. Wirtschaftspolitische Bltter, volume 53.

Dias, D. A. and Richmond, C. (2007). 'Duration of Capital Market Exclusion: An Empirical Investigation'. Working Paper, UCLA.

Durdu, C. B., Nunes, R., and Sapriza, H. (2013). 'News and sovereign default risk in small open economies'. Journal of International Economics, volume 91(1), 1-17.

Eaton, J. and Gersovitz, M. (1981). 'Debt with potential repudiation: theoretical and empirical analysis'. Review of Economic Studies, volume 48, 289-309.

EC (2006). 'Public nances in EMU'. European Commission. No. 3. 
Feld, L. P., Kalb, A., Moessinger, M.-D., and Osterloh, S. (2013). 'Sovereign Bond Market Reactions to Fiscal Rules and No-Bailout Clauses The Swiss Experience'. ZEW Discussion Paper No. 13-034.

Garcia, C. J., Restrepo, J. E., and Tanner, E. (2011). 'Fiscal rules in a volatile world: A welfare-based approach'. Journal of Policy Modeling, volume 33, 649-676.

Gavin, M. and Perotti, R. (1997). 'Fiscal Policy in Latin America'. NBER Macroeconomics Annual, pages $11-71$.

Gelos, G., Sahay, R., and Sandleris, G. (2011). 'Sovereign Borrowing by Developing Countries: What Determines Market Access?' Journal of International Economics, volume 83, 243-254.

Ghosh, A. R., Kim, J. I., Mendoza, E. G., Ostry, J. D., and Qureshi, M. S. (2011). 'Fiscal Fatigue, Fiscal Space and Debt Sustainability in Advanced Economies'. NBER Working Paper 16782.

Hatchondo, J. C. and Martinez, L. (2009). 'Long-duration bonds and sovereign defaults'. Journal of International Economics, volume 79, 117-125.

Hatchondo, J. C. and Martinez, L. (2013). 'Sudden Stops, Time Inconsistency, and the Duration of Sovereign Debt'. International Economic Journal, volume 27 (2), 217-228.

Hatchondo, J. C., Martinez, L., and Sapriza, H. (2010). 'Quantitative properties of sovereign default models: solution methods matter'. Review of Economic Dynamics, volume 13, no. 4, 919-933.

Hatchondo, J. C., Martinez, L., and Sosa Padilla, C. (2014a). 'Debt dilution and sovereign default risk'. Working Paper, McMaster University.

Hatchondo, J. C., Martinez, L., and Sosa Padilla, C. (2014b). 'Voluntary Sovereign Debt Exchanges'. volume $61,32-50$.

Heinemann, F., Kalb, A., and Osterloh, S. (2014). 'Sovereign risk premia: the link between fiscal rules and stability culture'. Journal of International Money and Finance, volume 41, 110-127. 
Iara, A. and Wolff, G. (2011). 'Rules and risk in the euro area'. Bruegel Working Paper 2011/10, Brussels.

Ilzetzki, E., Mendoza, E. G., and Végh, C. A. (2012). 'How big (small?) are scal multipliers?' Journal of Monetary Economics.

IMF (2009). 'Fiscal Rules: Anchoring Expectations for Sustainable Public Finances'. Fiscal Affairs Department, International Monetary Fund.

IMF (2013a). 'Fiscal Monitor: Fiscal Adjustment in an Uncertain World'. April.

IMF (2013b). 'Staff Guidance Note for Public Debt Sustainability Analysis in Market-Access Countries'. International Monetary Fund.

IMF (2013c). 'Staff Guidance Note on the Application of the Joint Bank-Fund Debt Sustainability Framework for Low-Income Countries'. International Monetary Fund.

Kaminsky, G., Reinhart, C., and Végh, C. (2004). 'When It Rains, It Pours: Procyclical Capital Flows and Macroeconomic Policies'. NBER Macroeconomics Annual, pages 11-53.

Kopits, G. (2004). 'Overview of Fiscal Policy Rules in Emerging Markets'. in Rules-Based Fiscal Policy in Emerging Markets. Background, Analysis, and Prospects, volume Kopits, G. (ed.).

Li, W. and Sarte, P.-D. (2006). 'U.S. consumer bankruptcy choice: The importance of general equilibrium effects'. Journal of Monetary Economics, volume 53, 613-631.

Livshits, I., MacGee, J., and Tertilt, M. (2008). 'Consumer Bankruptcy: A Fresh Start,'. American Economic Review, volume 97, 402-418.

Lizarazo, S. (2005). 'Sovereign risk and risk averse international investors'. Working Paper, ITAM.

Lizarazo, S. (2006). 'Contagion of financial crises in sovereign debt markets'. Working Paper, ITAM. 
Lorenzoni, G. and Werning, I. (2014). 'Slow Moving Debt Crises'. Manuscript, MIT.

Lowry, R. and Alt, J. (2001). 'A visible hand? Bond markets, political parties, balanced budget laws, and state government debt'. Economics 83 Politics, volume 13(1), 49-72.

Medina, J. P. and Soto, C. (2007). 'Copper price, fiscal policy, and busines cycle in Chile'. Central Bank of Chile Working Paper 458.

Mendoza, E. and Yue, V. (2012). 'A General Equilibrium Model of Sovereign Default and Business Cycles'. The Quarterly Journal of Economics. Forthcoming.

Neumeyer, P. and Perri, F. (2005). 'Business cycles in emerging economies: the role of interest rates'. Journal of Monetary Economics, volume 52, 345-380.

Pappa, E. and Vassilatos, V. (2007). 'The unbearable tightness of being in a monetary union: Fiscal restrictions and regional stability'. European Economic Review, volume 51, 1492-1513.

Poplawski Ribeiro, M., Beetsma, R., and Schabert, A. (2008). 'A Comparison of Debt and Primary-deficit Constraints'. CEPR Discussion Paper No. 6897.

Poterba, J. (1996). 'Budget Institutions and Fiscal Policy in the U.S. States'. American Economic Review, volume 86(2), 395-400.

Poterba, J. M. and Rueben, K. (1999). 'State fiscal institutions and the U.S. municipal bond market'. In Fiscal Institutions and Fiscal Performance, James Poterba and Jorgen von Hagen editors, University of Chicago Press.

Pouzo, D. and Presno, I. (2013). 'Sovereign Default Risk and Uncertainty Premia'. Manuscript, UC Berkeley.

Pouzo, D. and Presno, I. (2014). 'Optimal Taxation With Endogenous Default Under Incomplete Markets'. Manuscript, UC Berkeley.

Reinhart, C., Rogoff, K. S., and Savastano, M. A. (2003). 'Debt Intolerance'. Brookings Papers on Economic Activity. 
Reinhart, C. M., Reinhart, V., and Rogoff, K. S. (2015). 'Dealing with Debt'. Journal of International Economics, forthcoming.

Roch, F. and Uhlig, H. (2014). 'The Dynamics of Sovereign Debt Crises and Bailouts'. Mimeo, University of Chicago.

Sanchez, J. M. (2010). 'The IT Revolution and the Unsecured Credit Market'. Federal Reserve Bank of St. Louis Working Paper.

Sandleris, G., Sapriza, H., and Taddei, F. (2011). 'Indexed Sovereign Debt: An Applied Framework'. Collegio Carlo Alberto Working Paper No. 104.

Schaechter, A., Kinda, T., Budina, N., and Weber, A. (2012). 'Fiscal Rules in Response to the CrisisToward the Next-Generation Rules. A New Dataset'. IMF Working Paper 12/187.

Talvi, E. and Végh, C. (2009). 'Tax Base Variability and Procyclicality of Fiscal Policy'. Journal of Development Economics, volume 78(1), 156-90.

Tanner, E. and Samaké, I. (2006). 'Probabilistic Sustainability of Public Debt: A Vector Autoregression Approach for Brazil, Mexico, and Turkey'. IMF Working Paper 06/295.

Trebesch, C. and Wright, M. L. J. (2013). 'A Default Measure of Sovereign Default'. Mimeo.

Végh, C. A. and Vuletin, G. (2011). 'How is tax policy conducted over the business cycle?' Mimeo, University of Maryland.

Yue, V. (2010). 'Sovereign default and debt renegotiation'. Journal of International Economics, volume 80 , no. $2,176-187$. 